\title{
SRWC bioenergy productivity and economic feasibility on marginal lands
}

\author{
Solomon B. Ghezehei*, Shawn D. Shifflett, Dennis W. Hazel, Elizabeth Guthrie Nichols \\ Department of Forest and Environmental Resources, NC State University, \\ Raleigh, NC, 27695, USA
}

*CORRESPONDING AUTHOR:

$\begin{aligned} & \text { Solomon B. Ghezehei } \\ \text { EMAIL: } & \underline{\text { sbghezeh @ ncsu.edu }} \\ \text { MAIL ADDRESS: } & \begin{array}{l}\text { NC State University } \\ \text { Campus Box 8008 }\end{array} \\ & \text { Raleigh, NC 27695-8008 USA } \\ & +1(919) \text { 513-1371 } \\ \text { PHONE: } & \begin{aligned} \text { FAX: } & +1(919) 515-6886\end{aligned}\end{aligned}$




\section{Abstract}

Evolving bioenergy markets necessitate consideration of marginal lands for woody biomass production worldwide particularly the southeastern U.S., a prominent wood pellet exporter to Europe. Growing short rotation woody crops (SRWCs) on marginal lands minimizes concerns about using croplands for bioenergy production and reinforces sustainability of wood supply to existing and growing global biomass markets. We estimated mean annual aboveground green biomass increments (MAIs) and assessed economic feasibility of various operationally established (0.5 ha to 109 ha) SRWC stands on lands used to mitigate environmental liabilities of municipal wastewater, livestock wastewater and sludge, and subsurface contamination by petroleum and pesticides. MAIs $\left(\mathrm{Mg} \mathrm{ha}^{-1} \mathrm{yr}^{-1}\right)$ had no consistent relationship with stand density or age. Non-irrigated Populus, Plantanus occidentalis L. and Pinus taeda L. stands produced 2.4 to $12.4 \mathrm{Mg} \mathrm{ha}^{-1} \mathrm{yr}^{-1}$. Older, irrigated Taxodium distchum L., Fraxinus pennsylvanica L., and coppiced $P$. occidentalis stands had higher MAIs (10.6 to $21.3 \mathrm{Mg} \mathrm{ha}^{-1} \mathrm{yr}^{-1}$ ) than irrigated Liquidambar styraciflua L. and non-coppiced, irrigated P. occidentalis (8 to $18 \mathrm{Mg} \mathrm{ha}^{-1} \mathrm{yr}^{-1}$ ). Natural hardwood MAIs at 20 to 60 years were less than hardwood and $P$. taeda productivities at 5 to 20 years. Unlike weed control, irrigation and coppicing improved managed hardwood productivity. Rotation length affected economic outcomes although the returns were poor due to high establishment and maintenance costs, low productivities and low current stumpage values, which are expected to quickly change with development of robust global markets.

Keywords: Abandoned lands; contaminated lands; investment analysis; short-rotation forestry; sustainable feedstock production 


\section{Introduction}

In the U. S., the 2007 Energy Independence and Security Act sets a target of 136 billion liters (36 billion gallons) of renewable fuels for road transportation by 2022 (U.S. Congress, 2007; Al-Riffai et al., 2010). The National Defense Authorization Act of 2010 mandates that each Federal agency produces or consumes $25 \%$ of total energy from renewable energy sources beginning in 2025. In Europe, renewable energy directive 2009/28/EC dictates that by 2020, $20 \%$ of total energy and $10 \%$ of transport fuel consumptions of EU members should be from renewable energy sources (Scarlat et al., 2013). These mandates have re-invigorated national interest in renewable energy feedstocks and already shifted cropland use for bioenergy feedstocks, thus inflating commodity prices for food crops and livestock (Swinton et al., 2011). The U.S. needs 16 to 21 million ha of non-contentious land in order to meet the above target for cellulosic ethanol by 2022, (Lewis and Kelly, 2014) and Europe requires 17 to 30 million ha of land to achieve the $10 \%$ bioenergy target by 2020 (Scarlat et al., 2013).

To avoid using croplands for energy production and damaging forests and wetlands due to fast growing wood pellet production (Guo et al., 2015), worldwide efforts are underway to evaluate the use of marginal lands for bioenergy production (Gopalakrishnan et al., 2011; Fritz et al., 2012; Zumkehr and Campbell, 2013; Kang et al., 2013; Kells and Swinton, 2014; Lewis and Kelly, 2014; Stoof et al., 2014). The definition of marginal land varies (Kang et al., 2013) and has been used subjectively (Richards et al., 2014) but broadly describes lands not under cultivation due to low agro-economic values for major agricultural crops (Gopalakrishnan et al., 2011). The use of marginal lands for bioenergy production is appealing partly due to significant availability of marginal lands (Liu et al., 2011). Globally, the size of marginal lands available for bioenergy production could be 100 million to 1 billion ha (Milbrant and Overend, 2009, Zhuang et al., 2011, Kang et al., 2013). For most of the southeastern U.S., marginal croplands are largely wooded areas with poor soil productivity (Swinton et al., 2011). Lands may be "marginal" for 
conventional cropland use, but they may be appropriate and productive for bioenergy crops (Dickmann, 2006). Marginal land use for woody biomass production is also of intense interest given growing sustainability concerns of feedstock supplies to existing wood product markets and growing bioenergy markets. As urbanization continues to reduce forested acreage in the southeastern U.S., robust timber and wood pellet markets may alleviate this decline by expanding woody biomass production to marginal lands (Wear and Greis, 2013).

For the southeastern U.S., state, national, and international legislative mandates have grown bioenergy markets, particularly wood pellet production. In 2012, for instance, the U. S. produced over $21 \%$ of global wood pellet, which is expected to reach 45.2 million tonne by 2020 (Guo et al., 2015). Annual European wood pellet import is expected to reach over 21.8 million by 2015 (O’Carroll, 2012) predominantly expected from the southeastern U.S. where 21 wood pellet plants were in operation by 2013 (RISI, 2013). U.S. wood pellet exports to Europe increased from 1.3 million tonne in 2012 (Guo et al., 2015) to 2.9 million tonne in 2013, mainly from the southeastern U.S. due to high wood supply and proximity to processing plants and maritime shipping ports to European markets, thus reducing transportation costs, which make up to $25 \%$ of wood pellet price at delivery (Dickmann, 2006; EIA, 2014). Growing demand is evident in the recent establishment of two wood pellet plants (Mullins et al., 2014) and several maritime port expansions in eastern North Carolina (NC) to meet regional and local wood pellet demands.

Sustainability guidelines now under development in Europe are expected to restrict the use of forestlands for bioenergy production. The International Wood Pellet Buyers Group, for instance, opposes bioenergy use of wood from natural wetlands, major forest component in the southeastern U.S. (IWPBG, 2011). In the U. S., the definition of eligible woody biomass for biofuels production credit under RFS2 (U.S. Congress, 2007) is expected to restrict wood feedstocks from natural forest stands that comprise about $80 \%$ of southeastern forests (Huggett $e t$ 
al., 2013). Several studies evaluated biomass productivity of managed sycamore, sweetgum, green ash, and cottonwood plantations (Torreano and Frederick, 1988, Kennedy, 1981, Francis, 1982, Krinard and Kenney, 1983) and natural hardwood stands (Messina et al., 1986; Gower et al., 1985) for energy production in the coastal southeastern U.S. Currently, the species composition of managed woody bioenergy plantations likely includes Populus species, Plantanus occidentalis L. (sycamore), Liquidambar styraciflua L. (sweetgum), and Pinus taeda L. (loblolly pine) (Kennedy, 1981; Perlack et al., 1986; Dickmann, 2006).

The economic feasibility of woody biomass productivity varies considerably based on site conditions, planting densities, management, rotation length and species. The prices of the woody bioenergy products is more critical to economic feasibility than productivity (Schweier and Becker, 2013). Currently, profitability of Populus and Salix cannot compete with profits from traditional grass crops (hay) on marginal lands since woody bioenergy markets are not established (Kells and Swinton, 2014). For the southeastern U.S., markets already exist for traditional wood product uses, and the wood pellet market is established and growing (RISI, 2013). The efforts of the EU to provide stable and robust market environment for bioenergy is expected to play a leading role in increasing the values of bioenergy products, particularly in the southeastern U.S.

Information on marginal land suitability for sustainable bioenergy production is lacking (Liu et al., 2011) and little is known about the economic feasibility of what trees species to grow, which marginal lands to use, and total capacity for production. We define marginal lands as idle and abandoned croplands and pasturelands, woods, lands with environmental liabilities, contaminated and permitted-use lands such as wastewater application fields. We evaluated wood biomass productivity of managed stands on diverse marginal lands with stand ages of five to 20 years and sizes ranging from 0.1 to 149 hectares for the aforementioned species, Taxodium disctchum L. (bald cypress) and Fraxinus pennsylvanica (L.) Marshall (green ash). Their 
productivities were compare with those of native hardwood forest stands and their economic viability were assessed to determine what type of woody biomass to grow on marginal lands for bioenergy production within five to 20 year rotations. Although the stands were not managed as systematically and carefully as research plots would have been managed, they provide real-world operational productivity estimates of species recommended as SRWCs on various marginal lands. The stands are used to mitigate problems such as nutrient management or groundwater contamination by fuels or pesticides.

\section{Materials and Methods}

\subsection{Site Description}

We inventoried seven sites in NC (Fig. 1); details of size, age and type of the sites, mean annual rainfall, irrigation (if provided), stand species and management, and soil profiles are provided in Table 1. Annual rainfall was determined as the average rainfall of each year during the lifetime of each stand using weather data provided by the State Climate Office of NC. Mean annual irrigation was calculated from facility records for the last ten years for Garner and the last three years for Edenton.

\section{Fig. 1}

\section{Table 1}

Because Elizabeth City site was planted in 2006 and 2007, productivity was determined for each stand establishment. The stands at Edenton were coppiced in 1997 and 2008 by a professional logger so productivity represents growth from second coppice (during third rotation). At the other sites, stand management was minimal with no thinning. Weed control consisted of periodic mowing at all sites except Mount Olive where glyphosate $(N$ (phosphonomethyl)-glycine) was also used as a chemical control. At the Johnston County (JC) site, mean soil nitrate and Kdjedahl nitrogen concentrations in 2011 (nine years after land

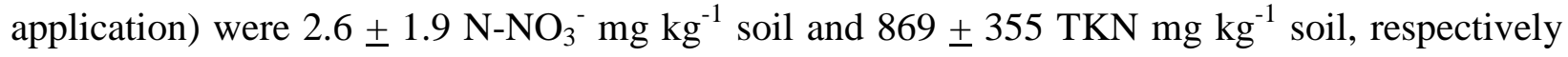


and $P$. taeda was planted in 2007. The distribution of nitrogen in the material used for the lagoon closure at Nash County is not known. For the municipal wastewater land application sites, mean nitrogen and phosphorus loadings per tree were $0.14 \mathrm{~kg}$ and $0.020 \mathrm{~kg}$ respectively. Since nitrogen and phosphorous loadings were addressed only for some of the sites (due to the size of the sites, significant investment would be required to adequately address this point) and coefficients of variation of the means were nearly $50 \%$ if not higher, they are not discussed further.

\subsection{Inventory of Aboveground Biomass}

To determine stand productivity, tree heights and outside-bark diameters at breast height (DBHs) were measured for individual trees either by establishing random 0.04 ha sampling plots or inventorying all trees in a stand (Table 1). Tree heights and DBHs were determined using tree height poles, Suunto clinometers, logger tapes, and Lufkin Executive DBH measuring tapes. At least $10 \%$ of trees in the sampling plots were measured twice to provide field quality control for precision (Supplementary Table 2).

Productivity was determined as mean annual green aboveground biomass increment (MAI) in metric tons per hectare per year $\left(\mathrm{Mg} \mathrm{ha}^{-1} \mathrm{yr}^{-1}\right)$ by multiplying wood volumes $\left(\mathrm{m}^{3}\right)$ and wood density at $50 \%$ moisture content $\left(\mathrm{kg} \mathrm{m}^{-3}\right)$. The assertion of $50 \%$ moisture content of standing Populus trees is supported by our findings from standing hybrid poplars at Aberdeen, Elizabeth City and Nash County. The wood density of each species (Supplementary Table 1) was determined by multiplying medium density or average density obtained from a wood density database (World Agroforestry Centre, 2012) by 1.7. Outside-bark woody volumes were estimated using measured heights and DBHs and literature-derived equations (Supplementary Table 2). Because most of the stands were 10 years old or younger, we tested accuracies of literature-derived volume equations of L. styraciflua and P. occidentalis with equations developed by destructive sampling at Edenton and Mt. Olive. For both species, coefficients of 
determination of the literature-derived equations $\left(\mathrm{R}^{2}=1\right)$ were higher than those of the measurement-derived equations $\left(\mathrm{R}^{2}=0.96\right)$. Although form-class segmented volume equations (Clark et al., 1991) were also considered, they were not used in this study as the inventoried trees were too small to meet size requirements of the equations.

\subsection{Economic Analyses}

The economic feasibility of growing the stands for biomass feedstock was assessed by calculating net present value or NPV (El Kasmioui and Ceulemans, 2013), internal rate of return or IRR (Schmithüsen et al., 2014) and land expectation value (LEV) using costs and revenues, discount rates of 3\%, 5\% and 7\% and various rotation lengths (actual ages and three extended rotations). The U.S. Forest Service Quick-Silver software (Vasievich, 1999) Version 7.0 was used to calculate IRR and NPV. Where stand NPV was positive, equivalent annual value (EAV) was also calculated (Friday et al., 2000) to determine stand values in terms of annual income.

Costs of establishing and managing the stands were estimated based on available management history (Table 1) by discounting current activity and material costs for forestry or agricultural activities (University of Illinois, 2012) to the years of occurrence. No land rent or property taxes were considered. Costs during site establishment and management included groundcover suppression (using herbicides, mowing and sub-soiling), installation and maintenance of irrigation systems for irrigated stands (Wichelns et al., 1996), planting labor (NC Forest Services, 2014a) and post-planting weed management costs. Costs per seedling of $\$ 0.06$ for loblolly pine and \$0.30 for the other species were used (ArborGen 2013-2014; NC Forest Services, 2014b). Site maintenance costs included mowing and irrigation maintenance expenses (Wichelns et al., 1996; University of Illinois, 2012). To determine harvest and delivery costs, we used average hauling distance haul rates published by Timber Mart-South (TMS) for NC (region 2, first quarter of 2014) for a 40-tonne net log truck at an assumed rate of $2.13 \mathrm{~km}$ per liter (5 
miles per gallon) at $\$ 1$ per liter ( $\$ 3.80$ per gallon) diesel. No storage costs were considered as same-day harvesting and trucking was assumed.

We used two approaches to obtain a stumpage price for trees sold as energy feedstock. In the first, we used TMS delivered prices FOB Mill of pulpwood hardwood and subtracted harvest and delivery costs estimated in the manner described above and assuming all residual costs were paid as stumpage to landowners. The resulting estimated stumpage was $\$ 4.33$ per green tonne. In the second approach, we used average hardwood pulpwood stumpage price in the same report, which is $\$ 4.42$ per green tonne. For most of the southeastern U.S. including the region where our stands are located, no biofuel industry exists yet, however, two new wood pellet plants have recently been constructed that are rumored to pay "about pulpwood prices", although actual prices are not publically available. Given the small difference between the calculated and the reported average NC stumpages, we used reported stumpage in our analyses. For the younger stands, rotation was extended to 15,18 and 20 years by projecting productivity of the stands using species-specific MAIs obtained from Dickens et al. (2011) and references therein. Running scenarios for younger stands allowed evaluation of the effect of rotation lengths.

To analyze effects of increased stumpage values on economics feasibility, the stands were further analyzed using a TMS south-wide average stumpage value of $\$ 11.16$ per green tonne (fourth quarter of 2014) at rotation lengths of actual age, 10, 12, 15, 18 and 20 years. Where the south-wide stumpage price did not produce positive returns, break-even analyses were performed at these rotations. We did not address economies of scale of the stands as there is a great need to have larger studies established to address costs and economic profitability, which depend not only on biomass yields but also a variety of factors from site maintenance to product delivery to markets. 


\section{Results and Discussion}

\subsection{Biomass Productivity}

MAIs of the inventoried stands are presented in Fig. 2. Non-irrigated Populus and P. occidentalis stands had MAI of 2.4 to $5.3 \mathrm{Mg} \mathrm{ha}^{-1} \mathrm{yr}^{-1}$ and 2.5 to $7.6 \mathrm{Mg} \mathrm{ha}^{-1} \mathrm{yr}^{-1}$ respectively. Because water deficit can negatively affect Populus productivity (Monclus et al., 2006), lack of irrigation and periodic drought from 2005 to 2010 (NCDENR, 2009) may have limited MAIs of the Populus stands we studied. Non-irrigated P. taeda had MAI range of 5.1 to $12.4 \mathrm{Mg} \mathrm{ha}^{-1} \mathrm{yr}^{-1}$ during the same drought period without any weed suppression whereas the Populus and $P$. occidentalis stands were mowed periodically until canopy closure. More productive stands were older and irrigated $T$. distchum and $F$. pennsylvanica stands and irrigated and coppiced $P$. occidentalis stands (Fig. 2). The 19-year-old $F$. pennsylvanica stand was the most productive with MAI of 10.6 to $21.3 \mathrm{Mg} \mathrm{ha}^{-1} \mathrm{yr}^{-1}$. The 20-year-old T. distchum had MAI of $19 \pm 0.87 \mathrm{Mg}$ $\mathrm{ha}^{-1} \mathrm{yr}^{-1}$ while productivity of 20-year-old $F$. pennsylvanica stands ranged between 10.8 and 13.5 $\mathrm{Mg} \mathrm{ha}^{-1} \mathrm{yr}^{-1}$. Moderate to high MAIs were observed for coppiced L. styraciflua (10 to $12.1 \mathrm{Mg}$ $\mathrm{ha}^{-1} \mathrm{yr}^{-1}$ ) and P. occidentalis ( 8 to $18 \mathrm{Mg} \mathrm{ha}^{-1} \mathrm{yr}^{-1}$ ).

Our results suggest that irrigation and coppicing can improve biomass productivity on marginal lands and that opportunities to merge existing land applications of wastewater from municipalities, livestock feeding operations, aquaculture, food processing industries etc. with biomass production should be further explored. Sites with weed control were not necessarily more productive than sites without weed control although tree species varied among sites. As shown in Fig. 2, longer rotations generally increased MAI of Populus, while F. pennsylvanica, $L$. styraciflua and P. occidentalis had similar or generally higher MAIs at shorter rotations. Some marginal lands could be better producers than others as evidenced by higher productivity of nonirrigated Populus at Nash County (10 years old) than Aberdeen (15 years old) and higher 
productivities of irrigated $P$. occidentalis and L. styraciflua at Edenton (5 and 6 years old) than Garner (20 years old).

\section{Fig. 2}

Studies of Populus productivity on marginal lands in the U.S. provide a wide MAI range. Zalesny et al. (2007) reported aboveground MAI of 0.31 to $1.5 \mathrm{Mg} \mathrm{ha}^{-1} \mathrm{yr}^{-1}$ for 1.7 year-old high density stands $\left(3,472\right.$ trees $\left.\mathrm{ha}^{-1}\right)$ in Wisconsin irrigated with landfill leachate. Felix et al. (2007) reported MAI of 5.5 $\mathrm{Mg} \mathrm{ha}^{-1} \mathrm{yr}^{-1}$ for Populus trees grown in trenched municipal waste bio-solids in southern Maryland on three to six year rotations with no site maintenance. For Populus stands irrigated with municipal wastewater effluent, dry mass MAIs of $20 \mathrm{Mg} \mathrm{ha}^{-1} \mathrm{yr}^{-1}$ in central Florida (Sticker et al., 2001) and 21 to $50 \mathrm{Mg} \mathrm{ha}^{-1} \mathrm{yr}^{-1}$ for a two-year growth of a high density stand in north Florida (Minogue et al., 2012) have been reported. There are additional studies but conversion of the reported productivities to MAIs can lead to overestimations due to small study sizes (Kaczmarek et al., 2013) or young stand ages (Shifflett et al., 2014).

Published information on productivity of the other species we inventoried on marginal lands is limited. MAI of $P$. taeda in this study $\left(8.5 \mathrm{Mg} \mathrm{ha}^{-1} \mathrm{yr}^{-1}\right)$ was much greater than MAIs from other studies of $3.6 \mathrm{Mg} \mathrm{ha}^{-1} \mathrm{yr}^{-1}$ (Samuelson et al., 2004) and 3.9 $\mathrm{Mg} \mathrm{ha}^{-1} \mathrm{yr}^{-1}$ (Allen et al., 2005) for six-year-old pines. Frederick et al. (1998) reported that L. styraciflua at a municipal land application site in NC produced 3.8 $\mathrm{Mg} \mathrm{ha}^{-1}$ and $9.4 \mathrm{Mg} \mathrm{ha}^{-1}$ annually at five and ten years of age respectively. Coppiced five-year-old $P$. occidentalis had MAIs of 7 to $17 \mathrm{Mg} \mathrm{ha}^{-1} \mathrm{yr}^{-1}$ whereas non-coppiced $P$. occidentalis had MAIs of 9.6 $\mathrm{Mg} \mathrm{ha}^{-1} \mathrm{yr}^{-1}$ and $9.4 \mathrm{Mg} \mathrm{ha}^{-1} \mathrm{yr}^{-1}$ at five and ten years respectively at different wastewater land application sites in NC. MAIs of our noncoppiced stands are comparable to MAIs of managed stands in the northeast U.S. of $7 \mathrm{Mg} \mathrm{ha}^{-1}$ $\mathrm{yr}^{-1}$ (Tharakan et al., 2001), and north central U.S. of $9 \mathrm{Mg} \mathrm{ha}^{-1} \mathrm{yr}^{-1}$ (Netzer et al., 2002).

Natural hardwood stand management normally requires minimal to no site preparation and maintenance as forest stands are allowed to regenerate and thin naturally, requiring longer 
rotations (20 to 60 years) to reach acceptable size. For pulpwood and bioenergy products, rotations do not need to be as long. Data evaluating natural hardwood productivity for shorter rotation periods (5 to 20 years) in NC are not well documented. Merz (1965) reported $P$. occidentalis productivity of $6.2 \mathrm{Mg} \mathrm{ha}^{-1} \mathrm{yr}^{-1}$ for a 17-year-old natural stands in NC. $F$. pennsylvanica has had little MAI data published and the impending threat of Agrilus planipennis (emerald ash borer) is likely to reduce stand productivity and its consideration for commercial use. In Georgia, 27-year-old pulpwood stands with $80 \%$ composition of $F$. pennsylvanica had MAI of 6.0 Mg ha ${ }^{-1} \mathrm{yr}^{-1}$ (Kennedy, 1990). The MAIs of these two species were lower than MAIs of our irrigated stands (Fig. 2), and similar to that of our non-irrigated P. occidentalis.

Gardner et al. (1982), Messina et al. (1986), and Gower et al. (1985) provide extensive evaluations of productivity of natural hardwood stands in eight ecosystem types in southeastern U.S. ("Muck swamp", "Wet flat", "Red river bottom”, "Black river bottom”, "Branch bottom”, "Bottomland", "Coves, gulfs, lower slopes", and "Upland slopes and Ridges"). Fig. 3 and Fig. 4 compare MAIs of the natural stands with our observed MAIs based on stand density and age. There are no clear relationships between stand density and MAIs for the natural stands nor the stands we inventoried where stand densities varied for a particular species (Fig. 3). As a result, SRWCs can be planted at high density to maximize biomass production per unit land and facilitate biomass availability in shorter rotations in order to meet the rising feedstock demands. Likewise, stand age did not particularly increase or decrease MAIs of the natural stands (Fig. 4).

\section{Fig. 3}

MAIs of $F$. pennsylvanica and $T$. distchum in our study exceeded MAIs of the natural stands, which ranged from 5.9 to $16 \mathrm{Mg} \mathrm{ha}^{-1} \mathrm{yr}^{-1}$, particularly in bottom and swamp areas at 20 years (Fig. 4). More importantly, MAIs of the much younger P. taeda (non-irrigated and a softwood) and P. occidentalis (irrigated, coppiced and non-coppiced) on marginal lands were similar to or higher than MAIs of the 20-year-old natural stands (Fig. 4). Even without irrigation, 
P. taeda stands we inventoried had MAIs (5.14 to $12.4 \mathrm{Mg} \mathrm{ha}^{-1} \mathrm{yr}^{-1}$ ) comparable to most of the natural stands (except "Muck swamp" and "Wet flat" stands). These data justify further evaluations of marginal land productivity to meet growing bioenergy needs versus utilization of natural hardwood stands for non-traditional forestry product resources.

\section{Fig. 4}

\subsection{Economic Analyses}

The resultant low (negative) values of the economic parameters (Table 2) show that most stands were economically unfeasible as established and managed at current local (NC) stumpage prices for energy feedstocks. Factors that contributed to infeasibility included relatively high costs of establishment including weed management, subsoiling, seedlings, irrigation at the irrigated sites and extremely low stumpage price. In addition, the stands were not necessarily established and managed for high growth rates. While lower productivity, high costs or both made the other stands economically unfeasible, JC had positive returns due to high $P$. taeda productivity, absence of irrigation costs and lower establishment costs. We included the costs of installing irrigation because productivity would reflect the benefit of irrigation. However, it could be argued that because irrigation of some approved crops was required under their state discharge permit, the cost of irrigation could have been excluded, and only costs and incomes over and above normal irrigation practices could be included. Rotation length affected NPVs, LEVs and stumpage values indicating that determining rotation length using economic criteria is feasible.

\section{Table 2}

Although the economic parameters in Table 2 are not encouraging for bioenergy SRWCs production, few expect a viable industry to develop with the low NC stumpage values for pulpwood, which are historically among the lowest in the Southeast and can be expected to increase considerably as energy markets develop. As shown in Table 3, Populus stands at 
Aberdeen, Elizabeth City and Nash County had positive returns and Nash County showed profitability even at higher discount rate $(5 \%)$ using south-wide stumpage value $(\$ 11.16$ per green tonne). P. occidentalis stands at Edenton and Mount Olive showed positive returns in 10 to 12 years. Where the south-wide stumpage prices did not produce positive returns, stumpage prices required to break-even ranged between $\$ 11.33$ and $\$ 61.56$ per green tons.

\section{Table 3}

The economic performance of such stands can be improved by subsidization at establishment phase (Mitchell et al., 1999; Kasmioui and Ceulemans, 2013). Poor soils cannot support sufficient woody biomass productivity to justify intensive forestry investment on SRWCs (Dickmann, 2006) and the wastewaters at our study sites are not nutrient-rich. Active fertilization would benefit productivity of the stands by increasing their growth rates and supporting higher density, thus improving productivity and economic feasibility of the marginal lands for bioenergy production. SRWCs can grow well on marginal lands where water supply is not limiting; thus, irrigation systems with low capital and running costs should be preferred (Schweier and Becker, 2013). Cost-effective ways of integrating irrigation and fertilizer applications should be implemented in order to maximize productivity and economic feasibility.

Some studies have evaluated scenarios for the U.S. biofuels industry using a woody feedstock value as high as \$46 per dry tonne (Biomass Research and Development Board, 2009). As stumpage prices increase, economic viability of SRWCs will improve. However, reported production costs of SRWCs are high (Tyner et al., 2010) and some have noted that unless crude oil gets much higher, those prices will create a ceiling that will make most feedstocks including SRWCs too expensive to produce for a viable U.S. biofuels industry (Miranowski and Rosburg, 2012). Low oil prices are expected to reduce costs of SRWCs by reducing harvesting and transport costs. Heating oils and wood pellets have the same cost per unit energy at oil price of \$55 per barrel, below which stumpage values will fall as there is no floor under the stumpage 
prices. Although, lower demand and high supply of oil has reduced oil prices currently, it is reasonable to expect a $\$ 70$-per-barrel minimum oil price to be set at which heating oils would be costlier (FutureMetrics, 2014; Simet, 2014).

Our sampled stands were not established with the objective of high productivity rates, and improved growth rates of SRWCs should provide improved economic results but may not reduce production costs enough to make SRWCs economically viable (Miranowski and Rosburg, 2012). It is reasonable to expect feedstock stumpage prices to increase as robust markets develop, which is particularly important at lower stumpage prices (Buchholz and Volk, 2011). A significant effort in that aspect is that EU is working on providing stable market environments for bioenergy by setting mandatory bioenergy targets and polices conducive for investment decisions (Fouquet, 2013). At present, however, price-demand relationships for bioenergy stumpages are not established (Abt et al., 2012) and demand is not elastic to prices. Between second quarters of 2012 and 2013, for instance, U.S. South pulpwood pine demand increased by $3.7 \%$ and stumpage prices by $10 \%$, and hardwood stumpage price increased by $10.4 \%$ while demand was $2 \%$ lower (Forest2Market, 2013). Hence, it is difficult to predict when to expect higher stumpage prices or manage prices by regulating production or harvests. Stumpage values are affected by wood pellet prices in Europe, which are dictated mainly by U.S. bioenergy policies, political drivers in Europe, supply and costs of alternative raw materials of pellets and costs of alternative energy sources. More pellet plants are expected in southeastern U.S. where pellet production is less costly due to lower costs of feedstock and transport.

\section{Conclusions}

Our study showed irrigation and coppicing can improve biomass productivity of managed hardwood stands on marginal lands. Fertilizer application could also enhance productivity. Rotation length affected productivity and economic outcomes of stands we studied while weed control did not appear to affect productivity. Economic performance of such stands can be 
improved by minimizing costs and increasing growth rates and stumpage value. These efforts should be accompanied by planting the right species at the right place and for the right rotation length. The fact that younger stands had comparable to higher MAIs when compared to older natural hardwood stands in the southeastern U.S., and that their MAIs are expected to increase with age shows promising productivity potentials of marginal lands. Our findings justify further evaluations of SRWC productivity on marginal lands to meet growing bioenergy demands because worldwide marginal land availability is significant and these lands have the potential to provide sustainable bioenergy feedstock production without the need for using croplands and changing land use.

\section{Acknowledgements}

We are grateful for the support from U.S. Department of Agriculture, McStennis, Progress Energy, the City of Raleigh, the town of Mont Olive, the town of Edenton, and Hanor Farms Ltd. 


\section{References}

Abt K.L., R.C. Abt, C. Galik., 2012. Effects of bioenergy demands and supply response on markets, carbon, and land use. For Sci. 58(5), 523-538.

Allen, C.B., R.E. Will, M.A. Jacobson., 2005. Production efficiency and radiation use efficiency of four tree species receiving irrigation and fertilization. For. Sci. 51(6), 556-569.

Al-Riffai, P., B. Dimaranan, D. Laborde., 2010. European Union and United States Biofuel Mandates: Impacts on World Markets. Inter-American Development Bank. http://www.iadb.org (accessed 4 Mar. 2012).

ArborGen, 2013. ArborGen product catalogue (2013-2014). http://www.arborgen.us/uploads/ catalog/Digital-Arborgen-catolog.pdf (accessed 8 Sep 2014).

Belanger, R.P., 1973. Volume and weight tables for plantation-grown sycamore. Southeast For. Exp. Stn. Res. Pap. SE-107, USDA Forest Service, Asheville, NC. p. 10.

Biomass Research and Development Board, 2009. Increasing feedstock production for biofuels: Economic drivers, environmental implications, and the role of research. Biomass Research and Development Board. http://www.esd.ornl.gov/eess/8_Increasing_Biofuels_Feedstock_ Production.pdf (accessed 25 Aug. 2014).

Buchholz, T., T.A. Volk., 2011. Improving the profitability of Willow crops - Identifying opportunities with a Crop Budget Model. Bioenergy Res. 4, 85-95.

Clark, A., D.R. Phillips, D.J. Frederick., 1985. Weight, volume, and physical properties of major hardwood species in the Gulf and Atlantic Coastal Plains. Southeastern For. Exp. Stn. Res. Pap. SE-250. USDA Forest Service, Asheville, NC.

Clark, A., R.A. Souter, B.E. Schlaegel., 1991. Stem profile equations for southern tree species. Res. Pap. SE-282, USDA Forest Service, Asheville, p. 117.

Dickens, E.D., B. Borders, B. Jackson., 2011. Short rotation woody crops yield estimates for Georgia growers. Daniel B. Warnell School of For. Nat. Resour., Univ. of Georgia. Ser. 
Paper_6_July_2011.pdf (accessed 27 Jul. 2014).

Dickmann, D.I., 2006. Silviculture and biology of short-rotation woody crops in temperate regions: Then and now. Biomass Bioenergy. 30(8), 696-705.

EIA, 2014. U.S. Energy Information Administration (EIA): U.S. wood pellet exports double in 2013 in response to growing European demand. 22 May 2014. http://www.eia.gov/ todayinenergy/detail.cfm?id=16391 (accessed 12 Nov 2014).

El Kasmioui, O., R., Ceulemans., 2013. Financial analysis of the cultivation of short rotation woody crops for bioenergy in Belgium: Barriers and opportunities. Bioenergy Res. 6, 336350.

Felix, E., D.R. Tilley, G. Felton, E. Flamino., 2008. Biomass production of hybrid poplar (Populus sp.) grown on deep-trenched municipal biosolids. Ecol. Eng. 33(1), 8-14.

Forest2Market, 2013. Export Wood Pellet Facilities' Raw Material Delivered Cost Trends - US South (Posted on August 16, 2013). http://www.forest2market.com/blog/export-wood-pelletfacilities-raw-material-delivered-cost-trends (accessed 16 Mar 2015).

Fouquet, D., 2013. Policy instruments for renewable energy - From a European perspective. Renew. Energy. 49, 15-18.

Francis, J.K., 1982. Fallowing for cottonwood plantations: benefits carry to rotations end. South. For. Exp. Stat. USFS, New Orleans, LA.

Frederick, D.J., A.R. Rubin, S.J. Frederick, T.W. Woody., 1998. Renovation of municipal wastewater and biomass production in hardwood tree plantations. ASAE Annual International Meeting (12-16 July 1998) Pap No. 987032, Orlando, FL.

Friday, J.B., C. Cabal, J. Yanagida., 2000. Financial Analysis for tree farming in Hawaii. Dept. of Natural Resources and Environmental Management, Cooperative Extension Service, 
University of Hawaii. Resour. Manage. RM-9. http://www2.ctahr.hawaii.edu/oc/freepubs/ pdf/RM-9.pdf (accessed 12 Aug. 2014).

Fritz, S., L. See, M. van der Velde, R.A. Nalepa, C. Perger, C. Schill, I. McCallum, D. Schepaschenko, F. Kraxner, X. Cai, X. Zhang, S. Ortner, R. Hazarika, A. Cipriani, C. Di Bella, A.H. Rabia, A. Garcia, M. Vakolyuk, K. Singha, M.E. Beget, S. Erasmi, F. Albrecht, B. Shaw, M. Obersteiner., 2013. Downgrading recent estimates of land available for biofuel production. Environ. Sci. Technol. 47(3), 1688-1694. DOI: 10.1021/es303141h.

Gardner, W.E., P. Marsh, R.C. Kellison, D.J. Frederick., 1982. Yields of natural hardwood stands in the southeastern United States. Hardwood Res. Coop. Ser. No 1. School of For. Res., NC State Univ., Raleigh.

Gopalakrishnan, G., N.M. Cristina, S.W. Snyder., 2011. A novel framework to classify marginal land for sustainable biomass feedstock production. J. Environ. Qual. 40(5), 1593-1600.

Gower, S.T., R. Lea, D.J. Frederick, A. Clark, D.R. Phillips., 1985. Aboveground energy production and distribution of southeastern hardwood swamp forests. Biomass 7(3), 185-197.

Guo, M., W. Song, J. Buhain., 2015. Bioenergy and biofuels: history, status, and perspective. Renew. Sustain. Energy Rev. 42, 712-725.

Huggett, R., D.N. Wear, R. Li, J. Coulston, S. Liu., 2013. Chapter 5. Forecasts of forest conditions, in: Wear, D.N., Greis, J.G., (Eds.), The southern forest futures project: Summary report. Tech. Rep. SRS-GTR-168. USDA Forest Service. Asheville, NC.

IWPBG, 2011. Initiative Wood Pellets Buyers (IWPB) work group on sustainability: Sustainability principles Final Ver. 9 Nov. 2011. http://www.laborelec.be/ENG/wpcontent/uploads/2011/11/PELLCERT 2011_2011-11-09-IWPB-Sustainability_principles.pdf (accessed 8 Sep. 2014). 
Kaczmarek, D.J., D.R. Coyle, M.D. Coleman., 2013. Survival and growth of a range of Populus clones in central South Carolina USA through age ten: Do early assessments reflect longerterm survival and growth trends? Biomass Bioenergy. 49, 260-272.

Kang, S., W.M. Post, J.A. Nichols, D. Wang, T.O. West, V. Bandaru, R.C. Izaurralde., 2013. Marginal Lands: concept, assessment and management. J. Agric. Sci. 5(5), 129-139.

Kells, B.J., S.M. Swinton., 2014. Profitability of cellulosic biomass production in the Northern Great Lakes region. Agron. J. 106(2), 397-406.

Kennedy, H., 1981. Foliar nutrient concentrations and hardwood growth influenced by cultural treatments. Plant Soil. 63, 307-316.

Kennedy, H.E. Jr., 1990. Green Ash Fraxinus pennsylvanica Marsh. Silvics of North America, Vol. 2: Hardwoods, U.S. Dept. of Agriculture. http://www.na.fs.fed.us/spfo/pubs/ silvics_manual/volume_2/silvics_v2.pdf (accessed 28 Aug. 2014).

Krinard, R., H. Kennedy., 1983. Ten-year growth of five planted hardwood species with mechanical weed control on sharkey clay soil. South. For. Exp. Stat. So-303. USFS, New Orleans, LA.

Lewis, S.M., M. Kelly., 2014. Mapping the Potential for Biofuel Production on Marginal Lands: Differences in Definitions, Data and Models across Scales. ISPRS Int. J. Geo-Inf. 3, 430-459. Liu, T.T., B.G. McConkey, Z.Y. Ma, Z.G. Liu, X. Li, L.L. Cheng., 2011. Strengths, weaknesses, opportunities and threats analysis of bioenergy production on marginal land. Energy Procedia. 5, 2378-2386.

Messina, M.G., D.J. Frederick, A. Clark., 1986. Nutrient content and distribution in natural southern coastal plain hardwoods. Biomass. 10(1), 59-79.

Milbrandt, A., R.P. Overend., 2009. Assessment of Biomass Resources from Marginal Lands in APEC Economies. Energy Work. Gr. August 2009. http://www.nrel.gov/docs/ fy10osti/ 46209.pdf (accessed 12 Nov 2014). 
Minogue, P.J., M. Miwa, D.L. Rockwood, C.L. Mackowiak., 2012. Removal of nitrogen and phosphorus by Eucalyptus and Populus at a tertiary treated municipal wastewater sprayfield. Int. J. phytorem. 14(10), 1010-1023.

Miranowski, J. and A. Rosburg., 2012. Long-term biofuel projections under different oil price scenarios. AgBioForum, 16(1), 79-87. http://www.agbioforum.org (accessed 14 Aug. 2014).

Mitchell, C.P., E.A. Stevens, M.P. Watters., 1999. Short-rotation forestry - operations, productivity and costs based on experience gained in the UK. For. Ecol. Manage. 121, 123136.

Monclus R., E. Dreyer, M. Villar, F.M. Delmotte, D. Delay, J.M. Petit, F.Brignolas., 2006. Impact of drought on productivity and water use efficiency in 29 genotypes of Populus deltoides $\times$ Populus nigra. New. Phytol., 169(4), 765-777.

Mullins, K.A., A. Venkatesh, A.L. Nagengast, M. Kocoloski., 2014. Regional allocation of biomass to U.S. energy demands under a portfolio of policy scenarios. Environ. Sci. Technol. 48(5), 2561-2568.

Netzer, D.A., D.N. Tolsted, M.E. Ostry, J.G. Isebrands, D.E. Riemenschneider, K.T. Ward., 2002. Growth, yield and disease resistance of 7-to 12-year-old poplar clones in the north central United States. GTR-NC-229. USDA Forest Service. http://www.nrs.fs.fed.us/pubs/ gtr/gtr_nc229.pdf (accessed 25 Aug. 2014).

NC Division of Water Resources, 2009. North Carolina Drought Management Advisory Council - Annual activities report - 2009. Dept. of Env. and Nat. Res. Raleigh. http://www.ncdrought.org/documents/2009_annual_report.pdf (accessed 4 Sep. 2014).

NC Forest Services, 2014a. Prevailing rates for sub-practices: NCFS Forest Development Program. http://ncforestservice.gov/Managing_your_forest/pdf/fdp_prevailing _rates.pdf (accessed 25 Jul. 2014). 
NC Forest Services, 2014b. North Carolina trees for North Carolinians: Seedling catalog 20142015. http://ncforestservice.gov/nursery/pdf/NCFS_Tree_Seedling_Catalog.pdf (accessed 25 Jul. 2014).

O'Carroll, C., 2012. Biomass pellet prices - Drivers and outlook. What is the worst that can happen? Pöyry Management Consulting Ltd., London. http://www.platts.com/IM.Platts. Content/ProductsServices/ConferenceandEvents/2012/pc250/presentations/Cormac_OCarroll .pdf (accessed 15 Aug. 2014).

Parresol, B.R., J.E. Hotvedt, Q.V. Cao., 1987. A volume and taper prediction system for bald cypress. Can. J. For. Res. 17(3), 250-259.

Perlack, R.D., J.W. Ranney, W.F. Barron, J.H. Cushman, J.L. Trimble., 1986. Short-rotation intensive culture for the production of energy feedstocks in the U.S.: A review of experimental results and remaining obstacles to commercialization. Biomass. 9(2), 145-159.

Richards, B.K., C.R. Stoof, I.J. Cary, P.B. Woodbury., 2014. Reporting on marginal lands for bioenergy feedstock production: a modest proposal. Bioenergy Res. 7, 1060-1062.

RISI, 2013. Wood Biomass Market Report. www.woodbiomass.com/woodbiomass/news/EastEurope/Wood-Pellets/RISI-Global-wood-pellet-demand-biomass.html\# (accessed 4 Sep. 2014).

Samuelson, L.J., K. Johnsen, T. Stokes., 2004. Production, allocation, stemwood growth efficiency of Pinus taeda L. stands in response to 6 years of intensive management. For. Ecol. Manage. 192(1), 59-70.

Scarlat, N., J. Dallemand, M. Banja., 2013. Possible impact of 2020 bioenergy targets on European Union land use. A scenario-based assessment from national renewable energy action plans proposals. Renew. Sustain. Energy Rev. 18, 595-606.

Schmithüsen, F., B. Kaiser, A. Schmidhauser, S. Mellinghoff, K. Perchthaler, A.W. Kammerhofer., 2014. Entrepreneurship and management in forestry and wood processing - 
Principles of business economics and management processes. Routledge, Taylor and Francis Group, New York, p. 318-319.

Schweier, J., G. Becker., 2013. Economics of poplar short rotation coppice plantations on marginal land in Germany. Biomass Bioenergy. 59, 494-502.

Shelton, M.G., G.L. Switzer, L.E. Nelson, J.B. Baker, C.W. Mueller., 1982. The development of cottonwood plantations on alluvial soils: Dimensions, volume, phytomass, nutrient content and other characteristics. Tech. Bull. 113. Mississippi Agric. For. Exp. Stn., Mississippi State Univ. p. 46.

Shifflett, S.D., D.W. Hazel, D.J. Frederick, E.G. Nichols., 2014. Species trials of short rotation woody crops on two wastewater application sites in North Carolina, USA. BioEnergy Res. $7(1), 157-173$.

Simet, A., 2014. Pellet hoarding, market distortions and oil prices. Biomass Magazine 31October 2014. http://biomassmagazine.com/blog/article/2014/10/pellet-hoarding-market distortions- and-oil-prices (accessed 16 Mar 2015).

Stoof, C.R., Richards, B.K., Woodbury, P.B., Fabio, E.S., Brumbach, A., Cherney, J, Das, S., Geohring, L., Hansen, J., Hornesky, J., Mayton, H., Mason, C., Ruestow, G., Smart, L.B., Volk, T.A., Steenhuis, T.S., 2014. Untapped potential: Opportunities and challenges for sustainable bioenergy production from marginal lands in the northeast USA. Bioenergy Res. DOI: $10.1007 / \mathrm{S} 12155-014-9515-8$.

Strauss, W., 2014. What will be the Impact of Crashing Oil Prices on the US Premium Heating Pellet Markets? FutureMetrics LLC. http://futuremetrics.info/wp-content/uploads/2014/12/ UPDATED_Dec_2014_Oil_Prices_and_the_US_Premium_Pellet_Market.pdf (accessed 16 Mar 2015).

Stricker, J.A., D.L. Rockwood, S.A. Segrest, G.R. Alker, G.M Prine, D.M. Carter., 2001. Short rotation woody crops for Florida, in: Volk, T.A., Abrahamson, L.P., Ballard, J.L., 
(compilers), Proceedings of third biennial conference on Short rotation woody crops operations working group, NewYork, USA. 10-13 October 2000. College of Env. Sci. and For., State Univ. New York, USA. p. 15-23.

Swinton, S.M., B.A. Babcock, L.K. James, V. Bandaru., 2011. Higher U.S. crop prices trigger little area expansion so marginal land for biofuel crops is limited. Energy Policy. 39(9), 5254-5258.

Tasissa, G., H.E. Burkhart, R.L. Amateis., 1997. Volume and taper equations for thinned and unthinned loblolly pine trees in cutover, site-prepared plantations. South. J. Appl. For. 21(3), 146-152.

Tharakan, P.J., D.J. Robison, L.P. Abrahamson, C.A. Nowak., 2001. Multivariate approach for integrated evaluation of clonal biomass production potential. Biomass Bioenergy. 21(4), 237247.

Torreano, S.J., D.J. Frederick., 1988. Influence of site condition, fertilization and spacing on short rotation hardwood coppice and seedling yields. Biomass. 16, 183-198.

Tyner, W.E., S. Brechbill, D. Perkis., 2010. Cellulosic ethanol: feedstocks, conversion technologies, economics, policy options, in: Schnepf, R., (Coordinator), CRS Rep. for Congress, Congr. Res. Ser., Washington, DC.

U.S. Congress, 2007. Energy Independence and Security Act of 2007. 110 ${ }^{\text {th }}$ Congress. Public Law 110-140. 19 December 2007.

University of Illinois Extension, 2012. Farm business management - machinery cost estimates: field operations (May 2012). Dept. Agric. and Consumer Econ., Univ. Illinois http://www.farmdoc.illinois.edu/manage/machinery/field\%20operations\%202012.pdf (accessed 25 June 2014).

Vasievich, M., 1999. Quick-Silver: An Economic analysis tool. North Central Research Station, USDA Forest Service, http://econ.usfs.msu.edu/qsilver. 
Wear, D.N., J.G. Greis., 2013. Chapter 1. Design of the southern forest futures project, in: Wear, D.N., Greis, J.G., (Eds.), The southern forest futures project: summer report. SRS-GTR-168. USDA-Forest Service. Asheville, NC.

Wells, O.O., R.C. Schmidtling., 1990. Sycamore Platanus occidentalis L. Silvics of North America, Vol. 2: Hardwoods. U.S. Dept. of Agriculture. http://www.na.fs.fed.us/spfo/pubs/ silvics_manual/volume_2/silvics_v2 .pdf (accessed 28 Aug. 2014).

Wichelns, D., L. Houston, D. Cone, Q. Zhu, J. Wilen., 1996. Farmers describe irrigation costs, benefits: Labor costs may offset water savings of sprinkler systems. California Agric., Univ. of California, 50(1), 11-18.

World Agroforestry Centre, 2012. Tree functional attributes and ecological database. http://www.worldagroforestry.org/.

Zalesny, J.A., R.S. Zalesny Jr, D.R. Coyle, R.B. Hall., 2007. Growth and biomass of Populus irrigated with landfill leachate. For. Ecol. Manage. 248(3), 143-152.

Zhuang, D., D. Jiang, L. Liu, Y. Huang., 2011. Assessment of bioenergy potential on marginal land in China. Renew. Sustain. Energy Rev. 15, 1050-1056.

Zumkehr, A., J.E. Campbell., 2013. Historical U.S. cropland areas and the potential for bioenergy production on abandoned croplands. Environ. Sci. Technol. 47(8), 3840-3847. 


\section{Figure Captions}

Fig. 1 A map of locations of the inventoried stands in NC.

Fig. 2 Green MAI ( \pm 1 standard deviation) for the inventoried stands (with ages shown above the bars). "COMP" denotes comprehensive inventories (from Nash County and Elizabeth City) involving all living trees.

Fig. 3 Green MAI ( \pm 1 standard deviation) versus stand density for trees on (A) marginal lands in NC and (B) natural stands inventoried by Gardner et al. (1982), Messina et al. (1986), Gower et al. (1985).

Fig. 4 Green MAI ( \pm 1 standard deviation) versus age for trees on (A) marginal lands in NC and (B) natural stands inventoried by Gardner et al. (1982), Messina et al. (1986), Gower et al. (1985). 


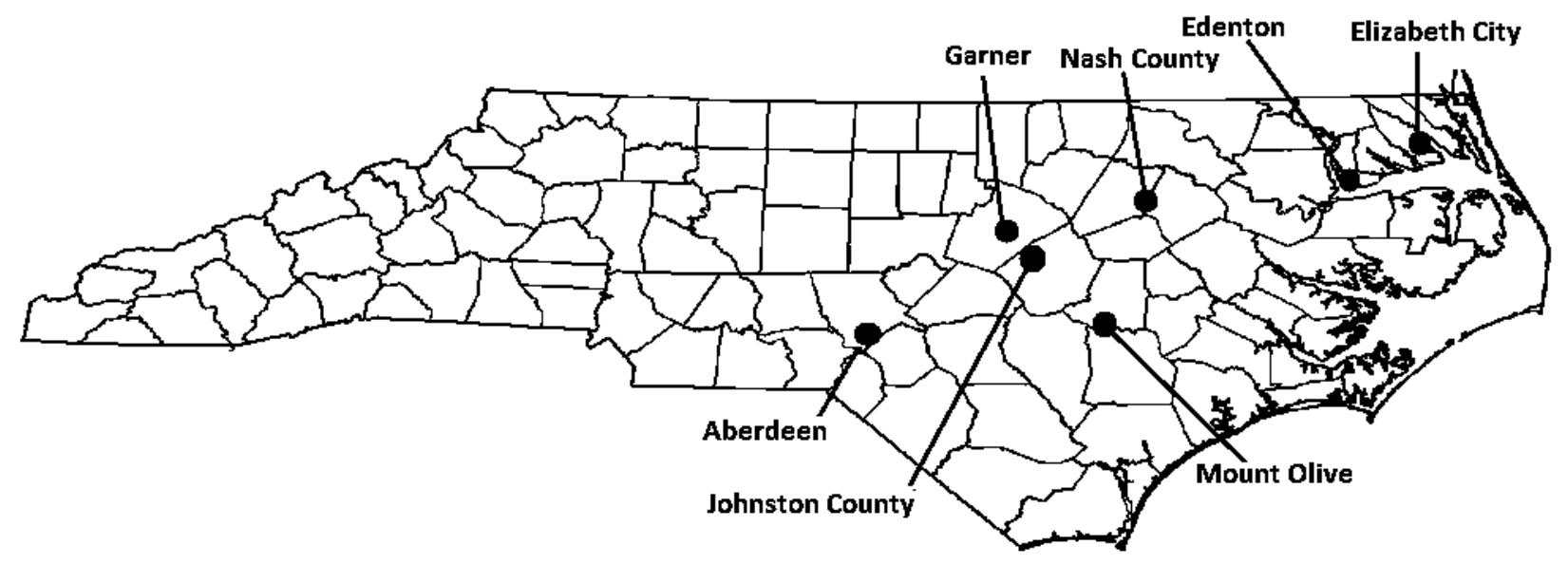

Fig. 1 

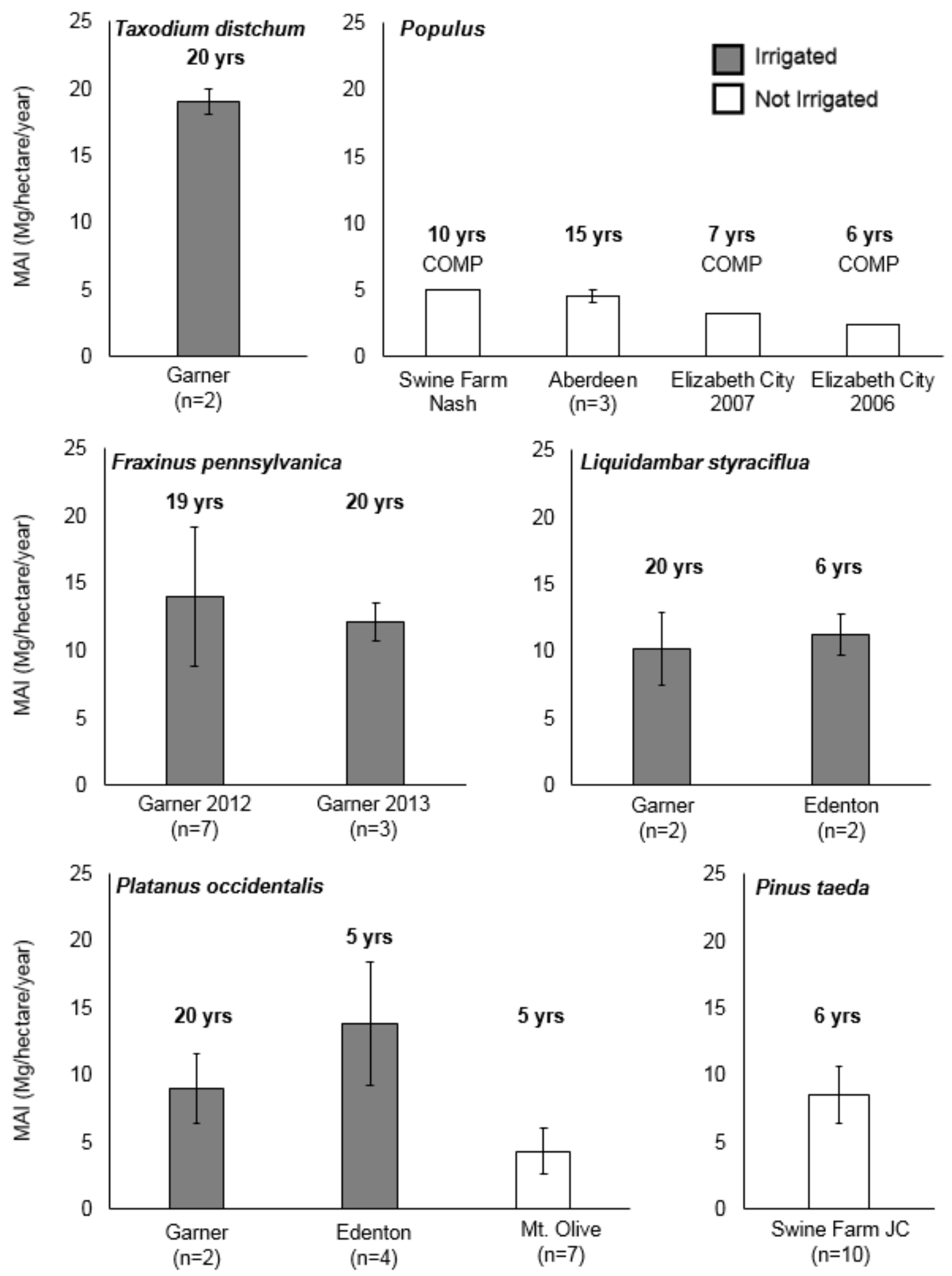

Fig. 2 

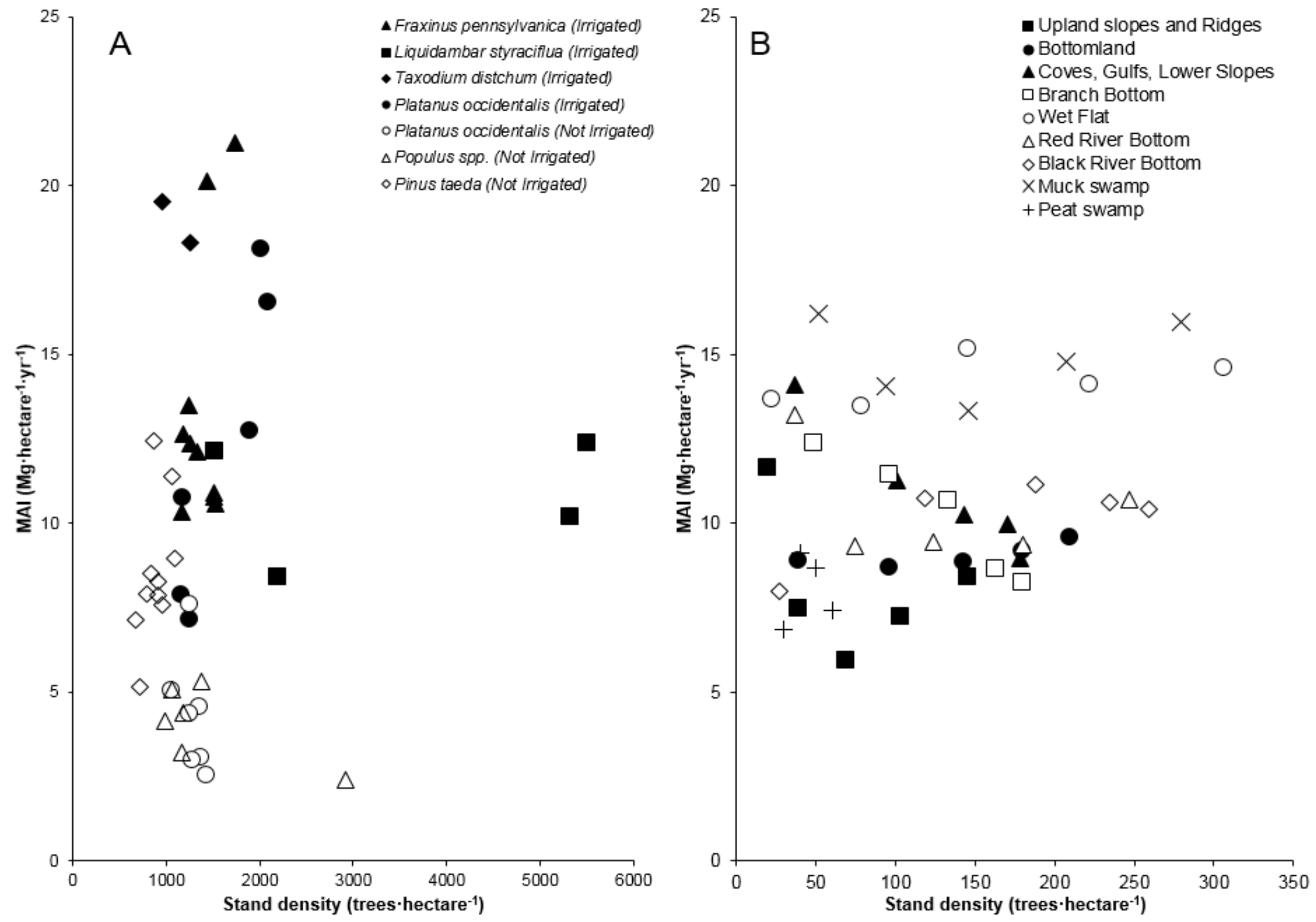

Fig. 3 

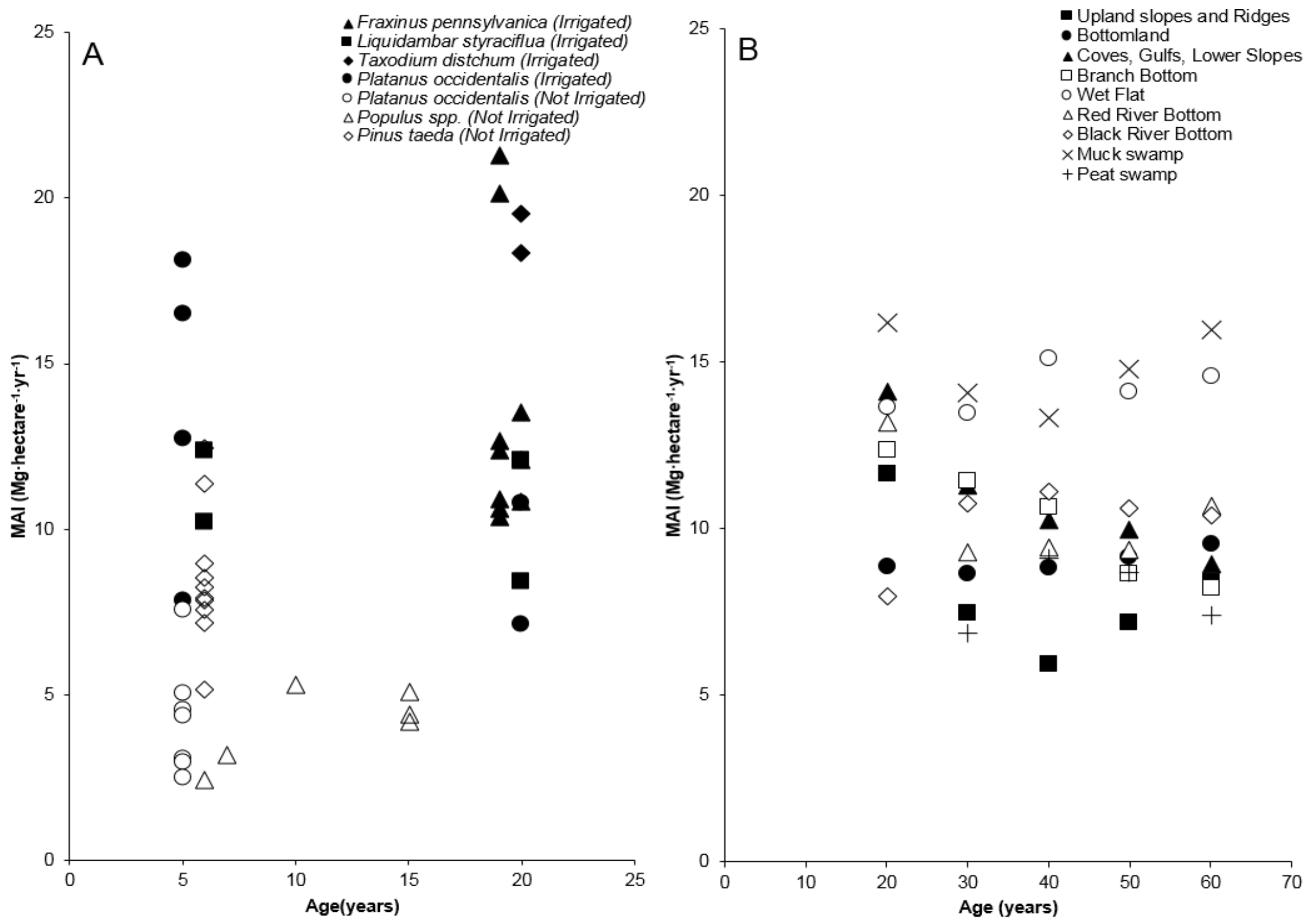

Fig. 4 
Table 1 Site information for inventoried stands in NC

\begin{tabular}{|c|c|c|c|c|c|c|}
\hline $\begin{array}{l}\text { Site (Age) } \\
\text { Site size (ha) } \\
\text { Sampled from }\end{array}$ & $\begin{array}{l}\text { Mean rainfall, } \\
\text { Irrigation }^{\dagger} \\
\text { (mm per } \\
\text { annum) }\end{array}$ & $\begin{array}{c}\text { Site } \\
\text { Details }\end{array}$ & $\begin{array}{c}\text { Tree } \\
\text { Species }\end{array}$ & $\begin{array}{l}\text { Trees per } \\
\text { hectare }\end{array}$ & $\begin{array}{l}\text { Weed / Stand } \\
\text { Management }\end{array}$ & Soil series \\
\hline $\begin{array}{l}\text { Aberdeen } \\
(15 \text { yrs.) } \\
1.4 \text { ha } \\
\text { ( } 3 \text { plots })\end{array}$ & $\begin{array}{l}1200 \\
\text { none }\end{array}$ & $\begin{array}{l}\text { Groundwater } \\
\text { Remediation } \\
\text { (Pesticides) }\end{array}$ & Populus & 1079 & Mowing/none & Vaucluse loamy sand \\
\hline $\begin{array}{l}\text { Edenton } \\
(5 \& 6 \text { yrs. }) \\
145 \text { ha } \\
(6 \text { plots })^{\S}\end{array}$ & $\begin{array}{r}1250 \\
1100^{\dagger}\end{array}$ & $\begin{array}{l}\text { Municipal } \\
\text { Wastewater Land } \\
\text { Application } \\
\text { Treatment of Primary } \\
\text { Wastewater }\end{array}$ & $\begin{array}{l}\text { L. styraciflua } \\
\text { P. occidentalis }\end{array}$ & $\begin{array}{l}5424 \\
1798\end{array}$ & $\begin{array}{l}\text { Mowing, coppice every } 6 \\
\text { years }\end{array}$ & $\begin{array}{l}\text { Fine sandy loam (Altavista, Dogue, Tomotley); Silt loam } \\
\text { (Chowan, Roanoke); Loamy sand (Conetoe, State); } \\
\text { Dorovan muck, Portsmouth loam, Roanoke silt loam }\end{array}$ \\
\hline $\begin{array}{l}\text { Elizabeth City } \\
(6 \& 7 \text { yrs.) } \\
2.0 \text { ha } \\
\text { (entire stand) }\end{array}$ & $\begin{array}{l}1250 \\
\text { none }\end{array}$ & $\begin{array}{l}\text { Groundwater } \\
\text { Remediation } \\
\text { (Petroleum/Fuels) }\end{array}$ & Populus & 2041 & $\begin{array}{l}\text { Mowing/trees trimmed to } \\
4 \text { feet every } 2 \text { yrs }\end{array}$ & Udorthent, loamy \\
\hline $\begin{array}{l}\text { Garner } \\
(20 \text { yrs. }) \\
109 \text { ha } \\
(11 \text { plots })^{\ddagger}\end{array}$ & $\begin{array}{c}1150 \\
1368^{\dagger}\end{array}$ & $\begin{array}{l}\text { Municipal } \\
\text { Wastewater Land } \\
\text { Application } \\
\text { Treatment of Primary } \\
\text { Wastewater }\end{array}$ & $\begin{array}{l}\text { F. pennsylvanica } \\
\text { L. styraciflua } \\
\text { P. occidentalis } \\
\text { T. distchum }\end{array}$ & $\begin{array}{l}1359 \\
1866 \\
1273 \\
1137\end{array}$ & Mowing/none & $\begin{array}{l}\text { Sandy loam (Altavista Appling, Buncombe Cecil, } \\
\text { Chewacla, Lynchburg, Mantachie, NorFolk, Pacolet, } \\
\text { Vance, Warne, Wedowee, Worsham); Silt loam } \\
\text { (Congaree, Wehadkee) Loamy sand (Durham, Louisburg); } \\
\text { Soils (Wehadkee, Bibb). }\end{array}$ \\
\hline $\begin{array}{l}\text { Johnston County } \\
\text { (6 yrs.) } \\
3.7 \text { ha } \\
\text { (10 plots) }\end{array}$ & $\begin{array}{l}1150 \\
\text { none }\end{array}$ & $\begin{array}{l}\text { Nutrient Remediation } \\
\text { of Former Swine } \\
\text { Waste Land } \\
\text { Application Field }\end{array}$ & P. taeda & 1076 & None/none & Cecil loam, sandy loam (Gillead, Marlboro), Pacolet loam. \\
\hline $\begin{array}{l}\text { Mount Olive } \\
(5 \text { yrs. }) \\
50 \text { ha } \\
\text { ( } 7 \text { plots })\end{array}$ & $\begin{array}{l}1200 \\
\text { none }\end{array}$ & $\begin{array}{l}\text { Municipal } \\
\text { Wastewater Land } \\
\text { Application } \\
\text { Treatment of Tertiary } \\
\text { Wastewater }\end{array}$ & P. occidentalis & 1292 & $\begin{array}{l}\text { Mowing, Glyphosate/ } \\
\text { trees trimmed to } 5 \text { feet } \\
\text { every year with herbicide }\end{array}$ & $\begin{array}{l}\text { Sandy loam (Bibb, Craven, Autryville, Norfolk, Johns, } \\
\text { Rains); Loamy sand (Ruston, Wagram, Kalmia, } \\
\text { Goldsboro, Norfolk); Loam (Chewacla, Johnston, } \\
\text { Pantego), soils (Johnston, Pamlico, Marvyn, Gritney); } \\
\text { Weston loamy fine sand }\end{array}$ \\
\hline $\begin{array}{l}\text { Nash County } \\
(10 \text { yrs.) } \\
0.13 \text { ha } \\
\text { (entire stand) }\end{array}$ & $\begin{array}{l}1200 \\
\text { none }\end{array}$ & $\begin{array}{l}\text { Alternative Lagoon } \\
\text { Closure Procedure }\end{array}$ & Populus & 1373 & None/none & Bonneau loamy sand, Gritney sandy loam \\
\hline
\end{tabular}


Table 2 Results of economic analyses of the Populus (Pop), P. occidentalis (Po), L. styraciflua (Ls), P. taeda (Pt), T. disctchum (Td) and F. pennsylvanica $(F p)$ stands

\begin{tabular}{|c|c|c|c|c|c|c|c|c|c|c|c|c|c|c|}
\hline \multirow{2}{*}{$\begin{array}{l}\text { Economic } \\
\text { metric }\end{array}$} & \multirow{2}{*}{$\begin{array}{l}\text { Age } \\
\text { (yrs.) }\end{array}$} & \multirow{2}{*}{$\begin{array}{l}\text { Discount } \\
\text { rate }\end{array}$} & Aberdeen & \multicolumn{2}{|c|}{ Edenton } & \multirow{2}{*}{$\begin{array}{c}\text { Elizabeth } \\
\text { City } \\
\text { Pop }\end{array}$} & \multicolumn{5}{|c|}{ Garner } & \multirow{2}{*}{$\begin{array}{c}\text { Johnston } \\
\text { County } \\
P t\end{array}$} & \multirow{2}{*}{$\begin{array}{c}\text { Mount } \\
\text { Olive } \\
\text { Po }\end{array}$} & \multirow{2}{*}{$\begin{array}{c}\text { Nash } \\
\text { County } \\
\text { Pop }\end{array}$} \\
\hline & & & Pop & Po & Ls & & $\begin{array}{c}F p \\
\text { (19 yrs.) }\end{array}$ & $\begin{array}{c}F p \\
(20 \text { yrs.) }\end{array}$ & Ls & Po & $T d$ & & & \\
\hline \multirow{8}{*}{$\begin{array}{l}\text { LEV } \\
\text { (\$/ha) }\end{array}$} & Actual & \multirow{4}{*}{$3 \%$} & -249 & -682 & -1818 & -709 & -667 & -911 & -733 & -836 & -407 & -53 & -620 & -335 \\
\hline & 15 & & -249 & -268 & -1038 & -318 & - & - & - & - & - & 624 & -129 & -105 \\
\hline & 18 & & -202 & -80 & -822 & -205 & - & - & - & - & - & 770 & -32 & 0 \\
\hline & 20 & & -128 & 41 & -676 & -134 & - & -911 & -733 & -836 & -407 & 851 & 28 & 64 \\
\hline & Actual & \multirow{4}{*}{$5 \%$} & -311 & -704 & -1790 & -716 & -858 & -904 & -1050 & -957 & -689 & -82 & -620 & -364 \\
\hline & 15 & & -311 & -645 & -1244 & -430 & - & - & - & - & - & 362 & -257 & -208 \\
\hline & 18 & & -290 & -548 & -1115 & -362 & - & - & - & - & - & 426 & -203 & -147 \\
\hline & 20 & & -244 & -485 & -1026 & -319 & - & -904 & -1050 & -957 & -689 & 456 & -170 & -112 \\
\hline \multirow{8}{*}{$\begin{array}{l}\text { NPV (EAV) } \\
\left(\text { in } \$ \text { ha }^{-1}\right)\end{array}$} & Actual & \multirow{5}{*}{$3 \%$} & -406 & -573 & -997 & -856 & -1228 & -1276 & -1495 & -1364 & -937 & -69 & -653 & -430 \\
\hline & 15 & & -406 & -308 & -810 & -529 & - & - & - & - & - & $548(46)$ & -71 & -250 \\
\hline & 18 & & -382 & -260 & -772 & -452 & - & - & - & - & - & $682(50)$ & 99 & -168 \\
\hline & 20 & & -328 & -236 & -751 & -410 & $\therefore$ & -1276 & -1495 & -1364 & -937 & $755(51)$ & 180 & -122. \\
\hline & Actual & & -454 & -586 & -997 & -831 & -1375 & -1404 & -1587 & -1442 & -1177 & -95 & -639 & -449 \\
\hline & 15 & \multirow{3}{*}{$5 \%$} & -454 & -444 & -900 & -625 & - & - & - & - & - & $289(28)$ & -269 & -340 \\
\hline & 18 & & -455 & -431 & -890 & -591 & - & - & - & - & - & 343 (29) & -185 & -301 \\
\hline & 20 & & -429 & -430 & -888 & -577 & - & -1404 & -1587 & -1442 & -1177 & 365 (29) & -159 & -284 \\
\hline \multirow{4}{*}{$\begin{array}{c}\text { Stumpage } \\
\text { Values } \\
\left(\$ \mathbf{t}^{-1}\right)\end{array}$} & Actual & \multirow{4}{*}{ - } & 119 & 305 & 300 & 22 & 467 & 366 & 434 & 321 & 676 & 91 & 38 & 94 \\
\hline & 15 & & 119 & 915 & 749 & 280 & - & - & - & - & - & 597 & 502 & 249 \\
\hline & 18 & & 215 & 1098 & 899 & 371 & - & - & - & - & - & 765 & 685 & 342 \\
\hline & 20 & & 277 & 1220 & 999 & 431 & - & 366 & 434 & 321 & 676 & 877 & 807 & 404 \\
\hline \multirow{4}{*}{ IRR (\%) } & Actual & \multirow{4}{*}{ - } & ${ }^{\dagger} \mathrm{NA}$ & NA & ${ }^{\dagger} \mathrm{NA}$ & NA & NA & ${ }^{\dagger} \mathrm{NA}$ & ${ }^{\dagger} \mathrm{NA}$ & ${ }^{\dagger} \mathrm{NA}$ & ${ }^{\dagger} \mathrm{NA}$ & ${ }^{\dagger} \mathrm{NA}$ & ${ }^{\dagger} \mathrm{NA}$ & ${ }^{\dagger} \mathrm{NA}$ \\
\hline & 15 & & ${ }^{\dagger} \mathrm{NA}$ & ${ }^{\dagger} \mathrm{NA}$ & ${ }^{\dagger} \mathrm{NA}$ & ${ }^{\dagger} \mathrm{NA}$ & - & - & - & - & - & 9.18 & ${ }^{\dagger} \mathrm{NA}$ & ${ }^{\dagger} \mathrm{NA}$ \\
\hline & 18 & & ${ }^{\dagger} \mathrm{NA}$ & 1.17 & ${ }^{\dagger} \mathrm{NA}$ & ${ }^{\dagger} \mathrm{NA}$ & - & - & - & - & - & 9.12 & 1.13 & 1.42 \\
\hline & 20 & & ${ }^{\dagger} \mathrm{NA}$ & 1.50 & ${ }^{\dagger} \mathrm{NA}$ & ${ }^{\dagger} \mathrm{NA}$ & - & ${ }^{\dagger} \mathrm{NA}$ & ${ }^{\dagger} \mathrm{NA}$ & ${ }^{\dagger} \mathrm{NA}$ & ${ }^{\dagger} \mathrm{NA}$ & 8.97 & 1.61 & 2 \\
\hline \multirow{8}{*}{$\begin{array}{c}\text { Total } \\
\text { Present- } \\
\text { value Costs } \\
\left(\$ \mathbf{t}^{-1}\right)\end{array}$} & Actual & \multirow{4}{*}{$3 \%$} & -1542 & -4999 & -4643 & -1236 & -4826 & -4552 & -4255 & -3786 & -6034 & -1112 & -1100 & -1386 \\
\hline & 15 & & -1542 & -8762 & -6978 & -3118 & - & - & - & - & - & -4670 & -4458 & -2427 \\
\hline & 18 & & -2100 & -9432 & -7164 & -3566 & - & - & - & - & - & -5441 & -5379 & -2903 \\
\hline & 20 & & -2414 & -9785 & -7206 & -3810 & $\therefore$ & -4552 & -4255 & -3786 & -6034 & -5861 & -5903 & -3168 \\
\hline & Actual & \multirow{4}{*}{$5 \%$} & -1238 & -5884 & -5451 & -1161 & -3778 & -3590 & -3430 & -3057 & -4581 & -1006 & -1095 & -1223 \\
\hline & 15 & & -1238 & -8552 & -7040 & -2528 & - & - & - & - & - & -3546 & -3494 & -1942 \\
\hline & 18 & & -1648 & -9101 & -7191 & -2750 & - & - & - & - & - & -3904 & -3986 & -2199 \\
\hline & 20 & & -1821 & -9392 & -7225 & -2847 & - & -3590 & -3430 & -3057 & -4581 & -4053 & -4221 & -2318 \\
\hline
\end{tabular}

\footnotetext{
NA shows IRR values less than or equal to zero
} 
Table 3 Results of economic analyses of the stands using TMS average south-wide stumpage value (\$11.16 per green tonne) and stumpage values required to break-even under the current stand productivity levels

\begin{tabular}{|c|c|c|c|c|c|c|c|c|c|c|c|c|c|c|}
\hline \multirow{2}{*}{$\begin{array}{l}\text { Economic } \\
\text { metric }\end{array}$} & \multirow{2}{*}{$\begin{array}{l}\text { Age } \\
\text { (yrs.) }\end{array}$} & \multirow{2}{*}{$\begin{array}{l}\text { Discount } \\
\text { rate }\end{array}$} & Aberdeen & \multicolumn{2}{|c|}{ Edenton } & \multirow{2}{*}{$\begin{array}{c}\text { Elizabeth } \\
\text { City } \\
\text { Pop }\end{array}$} & \multicolumn{5}{|c|}{ Garner } & \multirow{2}{*}{$\begin{array}{c}\text { Johnston } \\
\text { County } \\
P t\end{array}$} & \multirow{2}{*}{$\begin{array}{c}\text { Mount } \\
\text { Olive } \\
\text { Po }\end{array}$} & \multirow{2}{*}{$\begin{array}{c}\text { Nash } \\
\text { County } \\
\text { Pop }\end{array}$} \\
\hline & & & Pop & Po & Ls & & $\begin{array}{c}F p \\
\text { (19 yrs.) }\end{array}$ & $\begin{array}{c}F p \\
(20 \text { yrs.) }\end{array}$ & Ls & Po & $T d$ & & & \\
\hline \multirow{12}{*}{$\begin{array}{c}\text { NPV } \\
\left(\$ \mathrm{ha}^{-1}\right)\end{array}$} & Actual & \multirow{6}{*}{$3 \%$} & -193 & -458 & -1552 & -755 & -242 & -401 & -758 & -718 & 424 & 210 & -532 & -175 \\
\hline & 10 & & - & 620 & -870 & -319 & - & - & - & - & - & 1105 & 107 & -175 \\
\hline & 12 & & - & 880 & -595 & -108 & - & - & - & - & - & 1474 & 543 & 47 \\
\hline & 15 & & -193 & 1374 & -253 & 162 & - & - & - & - & - & 1941 & 1108 & 331 \\
\hline & 18 & & 76 & 1700 & 14 & 379 & - & - & - & - & - & 2316 & 1561 & 562 \\
\hline & 20 & & 229 & 1872 & 155 & 498 & $\therefore$ & -401 & -758 & -718 & 424 & 2521 & 1813 & 691 \\
\hline & Actual & \multirow{6}{*}{$5 \%$} & -298 & -597 & -1665 & -743 & -734 & -819 & -1095 & -1010 & -268 & 148 & -532 & -242 \\
\hline & 10 & & - & 125 & -1223 & -414 & - & - & - & - & - & 818 & -50 & -242 \\
\hline & 12 & & - & 228 & -1079 & -274 & - & - & - & - & - & 1054 & 252 & -88 \\
\hline & 15 & & -298 & 474 & -937 & -117 & - & - & - & - & - & 1312 & 600 & 87 \\
\hline & 18 & & -137 & 560 & -867 & -15 & - & - & - & - & - & 1477 & 830 & 205 \\
\hline & 20 & & -57 & 579 & -851 & 29 & - & -819 & -1095 & -1010 & -268 & 1545 & 925 & 259 \\
\hline \multirow{6}{*}{$\operatorname{IRR}(\%)$} & Actual & \multirow{6}{*}{ - } & NA & ${ }^{\dagger} \mathrm{NA}$ & ${ }^{\dagger} \mathrm{NA}$ & ${ }^{\dagger} \mathrm{NA}$ & 2.19 & 1.73 & ${ }^{\dagger} \mathrm{NA}$ & ${ }^{\dagger} \mathrm{NA}$ & 4.1 & 12.67 & NA & ${ }^{\dagger} \mathrm{NA}$ \\
\hline & 10 & & - & 5.61 & ${ }^{\dagger} \mathrm{NA}$ & ${ }^{\dagger} \mathrm{NA}$ & - & - & - & - & - & 19.96 & 4.3 & ${ }^{\dagger} \mathrm{NA}$ \\
\hline & 12 & & - & 5.89 & 1.24 & 2 & - & - & - & - & - & 19.47 & 7.49 & 3.62 \\
\hline & 15 & & ${ }^{\dagger} \mathrm{NA}$ & 6.48 & 2.43 & 4.06 & - & - & - & - & - & 18.09 & 9.13 & 5.95 \\
\hline & 18 & & 3.61 & 6.45 & 3.03 & 4.91 & - & - & - & - & - & 16.64 & 9.41 & 6.74 \\
\hline & 20 & & 4.52 & 6.35 & 3.25 & 5.17 & - & 1.73 & ${ }^{\dagger} \mathrm{NA}$ & ${ }^{\dagger} \mathrm{NA}$ & 4.1 & 15.75 & 9.33 & 6.92 \\
\hline \multirow{12}{*}{$\begin{array}{l}\text { Stumpage } \\
\text { values } \\
\text { required to } \\
\text { break-even } \\
\quad\left(\$ \mathrm{t}^{-1}\right)\end{array}$} & Actual & \multirow{6}{*}{$3 \%$} & 15.78 & 14.37 & 22.56 & 61.27 & 12.67 & 14.23 & 18.06 & 18.62 & - & 6.12 & 40.84 & 13.76 \\
\hline & 10 & & - & - & 15.47 & 16.74 & - & - & - & - & - & - & - & 13.76 \\
\hline & 12 & & - & - & 13.76 & 12.56 & - & - & - & - & - & - & - & - \\
\hline & 15 & & 15.78 & - & 12.13 & - & - & - & - & - & - & - & - & - \\
\hline & 18 & & - & - & - & - & - & - & - & - & - & - & - & - \\
\hline & 20 & & - & - & - & - & 12.67 & 14.23 & 18.06 & 18.62 & - & - & - & - \\
\hline & Actual & \multirow{6}{*}{$5 \%$} & 20.71 & 15.85 & 25.67 & 61.56 & 17.98 & 20.56 & 26.06 & 26.85 & 13.14 & 6.49 & 54.83 & 19.02 \\
\hline & 10 & & - & - & 18.65 & 20.11 & - & - & - & - & - & - & 11.93 & 19.02 \\
\hline & 12 & & - & - & 17.24 & 15.71 & - & - & - & - & - & - & - & 13.06 \\
\hline & 15 & & 20.71 & - & 16.04 & 12.7 & - & - & - & - & - & - & - & - \\
\hline & 18 & & 14.04 & - & 15.52 & 11.33 & - & - & - & - & - & - & - & - \\
\hline & 20 & & 12.18 & - & 15.41 & - & 17.98 & 20.56 & 26.06 & 26.85 & 13.14 & - & - & - \\
\hline
\end{tabular}

\footnotetext{
${ }^{\dagger}$ NA shows IRR values less than or equal to zero
} 